\title{
TERRITORIAL ANALYSIS OF THE DYNAMICS AND STRUCTURE OF THE HOUSING STOCK IN ROMANIA BETWEEN 1990-2018
}

DOI: http://dx.doi.org/10.18509/GBP.2020.74

UDC: 640:303.71(498)"1990/2018"

\author{
Luminița-Mirela Lăzărescu \\ Vasile Efros \\ Vasilică-Dănuț Horodnic \\ „STtefan cel Mare" University of Suceava, The Faculty of \\ History-Geography, Departament of Geography, Romania
}

\begin{abstract}
Living is an essential part of human existence with strong social and economic implications at the society level. Ensuring and continuously improving housing conditions, as part of the quality of life, is an important social task that must be an essential concern of policy makers. The implementation of the targets of the national housing policies must, in time, produce quantitative and qualitative changes that will effectively lead to the improvement of the living conditions in all areas of residence.

This article aims to characterize the current situation of housing stock on the territory of Romania as a result of the changes that occurred between 1990-2018 in the structure and characteristics of the housing fund and to highlight a series of territorial disparities at different scales of analysis. The analysis was performed on a national level, regarding development regions and residence environments the following basic attributes of the housing fund being selected: number of dwellings; property form; age; typology of constructions; size and number of occupants; access to housing to infrastructure. For the analysis, statistical data from the censuses of 1992, 2002, 2011 and data corresponding to time series provided by the National Institute of Statistics, were used. The data were processed with the help of the Microsoft Excel and ArcGIS software programs, the graphic and cartographic representations obtained were the starting point for their interpretation, explanation of territorial disparities and the formulation of the study conclusions.

The results of the research highlighted the existence of a well represented quantitative housing fund, with a good dynamic at national level for the analyzed period, but marked by high inequalities on a county level (with increases between 50 and 3484 houses/year). The main deficiencies identified concern: the age of the buildings; their endowment with utilities, especially in the rural environment; the dominance of the private property that limits the possibilities of intervention; inequalities between the aspects that define living between the two living environments: urban and rural. The conclusions regarding the current endowment of the territory for housing, during the analyzed period, were formulated by reference to the identified aspects and to the established causal reports as well as to the European living standards.
\end{abstract}

Keywords: housing stock, dwelling, living environments, utilities, housing quality, dynamics 


\section{INTRODUCTION}

Housing is one of the basic needs of the population and access to housing is an important factor in maintaining and improving the quality of life, as well as an essential component of society [1]. Satisfaction of housing demand has an important social side because living, through its components, participates in the evaluation of the quality of human settlements and can be considered as an important component of the quality of life assessment [2]. On the other hand, the economic dimension, highlighted by the financial flows used for the construction, sale and maintenance of homes, must also be taken into account because it plays an important role in boosting the economy at local, regional and even national level.

The housing fund is defined as the totality of the existing housing units in a territory, regardless of the type of property: residential houses, specialized houses (homes for the elderly), apartments, service rooms and other housing units in other buildings useful for housing. The elementary unit of the dwelling fund is the individual dwelling. The dwelling (apartment) is the built unit consisting of one or more living rooms located at the same level of the building or at different levels, provided, in general, with outbuildings (kitchen, bathroom etc.) or with other service spaces, independent from a functional point of view, having a separate entrance from the staircase house, courtyard or street and which has been built, transformed or arranged in order to be used, in principle, by a single household [3].

The structure of the housing fund in each country reflects a bit of its history and political choices [4]. In communist and post - communist Romania, the dynamics of the housing construction sector and its segments (private/public ownership, rural/urban housing, individual/collective housing) was reflecting political, economic and living ideologies [5]. The analysis of the dynamics of the housing fund takes into account quantitative aspects such as: the evolution of the number of dwellings; change, over time, their distribution by residence areas; the size of the dwellings (habitable surface, number of rooms); qualitative aspects of which we mention: the typology of the buildings in which the dwellings are located, the form of ownership over the dwelling; providing housing with utilities. The approach can be supplemented by calculating some synthetic housing indicators (number of households in relation to the number of dwellings; number of inhabitants per dwelling; average number of rooms per inhabitant; living area per inhabitant; average area of a room etc.) and by observing their evolution during the analyzed period. Starting from these considerations, the present article tries to carry out an analysis of the dynamics of the housing stock at different scales (national and regional) related to the mentioned specific criteria that will provide answers to the following questions: "What are the current characteristics of the structure of the Romanian housing fund at national and regional level?"; "What are the most obvious changes highlighted by the evolution of the indicators during the analyzed period?"; "What were the causes of these changes?"; "How are these changes reflected on a territorial scale?"; "What are the elements that best highlight the changes produced at national and regional level within the housing fund for the period considered?".

\section{STUDY AREA}

The territory under study is that of Romania, a state located in the south-east of Central Europe, on the Danube in the Black Sea, bordering on the North and on a part of the East with Ukraine, in the East with the Republic of Moldova, in the South with Bulgaria, in 
South-west with Serbia and west with Hungary. The analysis of the dynamics of the housing stock, for the studied period, was related to the whole territory of the country, as well as to territorial subdivisions of the type of development regions and counties.

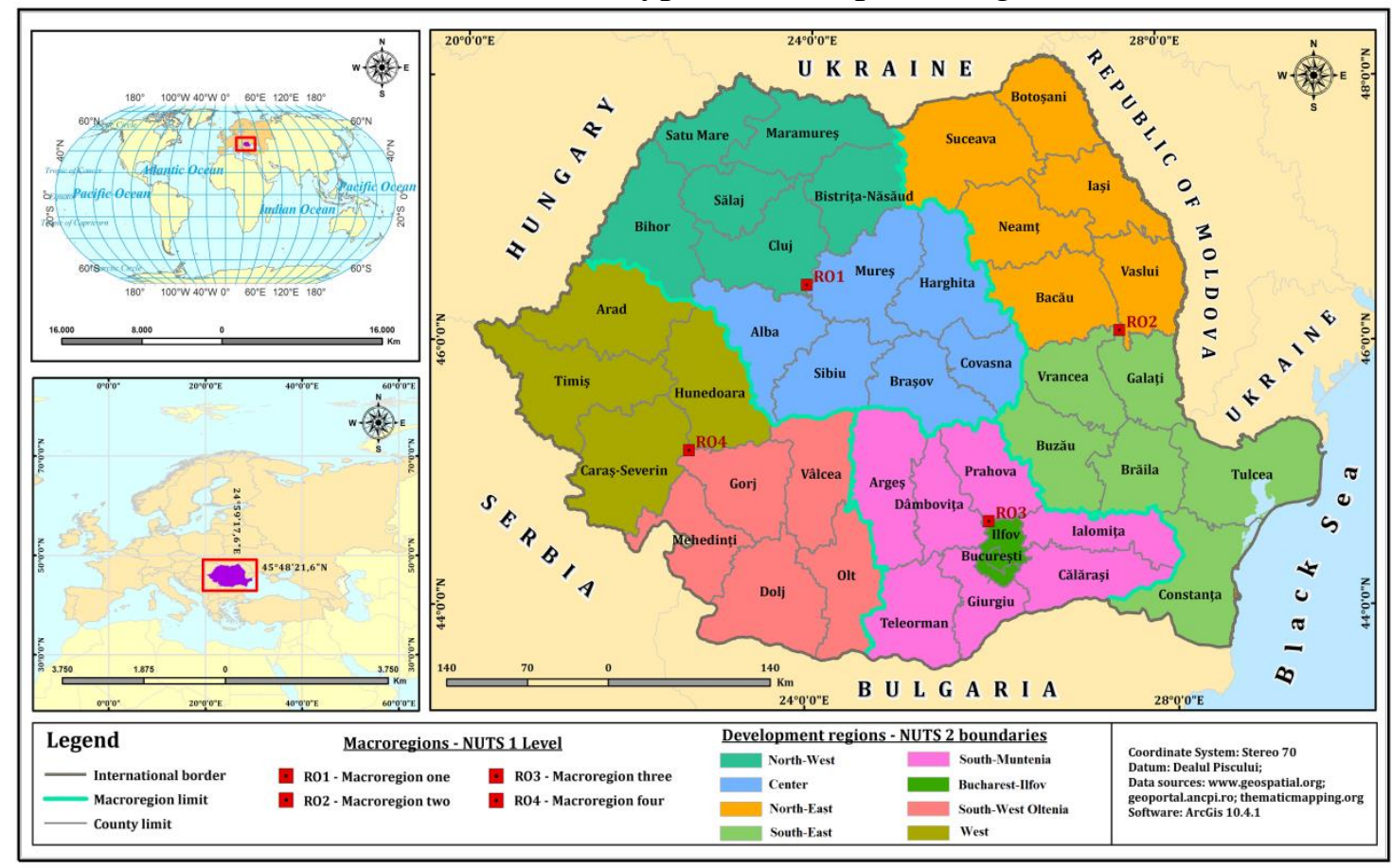

Figure 6. Location of the study area

\section{METHODOLOGY}

The research of the dynamics of the housing fund in Romania between 1990 and 2018 was based on the analysis and interpretation of statistical data. The source of data is the online European databases regarding the dynamics of housing stock in Romania, established by the Eurostat and the National Institute of Statistics after 1990 (Tempo Online database), the annual publications of the National Institute of Statistics (Housing Fund). The highlighting of the dynamics of the main characteristics of the housing fund started from the identification of the representative indicators, continued with the selection and processing of the statistical data corresponding to the years in the analyzed period, with the graphical representation of the evolution of some indicators and the interpretation of the obtained results. The research followed the evolution over time of the following indicators: number of dwellings, habitable surface, number of dwelling rooms, period of housing construction, type of building, access of housing built to utilities and a series of housing indicators (living area/dwelling; living area/person etc). The comparative analysis of the statistical data corresponding to the years 1990 and 2018 was, in most cases, based on the description of the way in which the housing stock evolved in the analyzed time interval, sometimes presenting the evolution through data series. The dynamics was illustrated by tables, graphical representations and interpretations that aimed at capturing the sense of evolution and highlighting some characteristics of the current housing fund in Romania at different scales of territorial analysis. The analysis at national and regional level (development regions) aimed in particular at explaining the dynamics of the housing fund highlighted by the evolution of the mentioned indicators, while the analysis at the subordinated territorial level (counties) aimed to capture the territorial disparities that appeared in the structure of the housing fund in within the 
development regions during the period studied. The results were represented cartographically using the Arc GIS program.

\section{RESULTS AND DISSCUSIONS}

\section{The dynamics of the national housing fund, between 1990 and 2018}

During post-communist period were modifed mechanisms and principles regarding housing construction and distribution. The elimination of mobility restrictions, of those concerning the access to ownership, the freedom to erect dwellings by own forces, the freedom of choosing desired residence place, are essential elements that transformed the structures of housing stock and residential characteristics of villages and towns [6].

Table 1. Romania - housing fund indicators and housing indicators for 1992 and 2018

\begin{tabular}{|c|c|c|c|c|c|c|}
\hline \multirow[t]{2}{*}{ Indicators } & \multicolumn{2}{|c|}{1 ianuarie 1993} & \multicolumn{2}{|c|}{1 ianuarie 2019} & \multicolumn{2}{|c|}{ Dynamics } \\
\hline & Total & $\begin{array}{c}\text { Urban } \\
(\%)\end{array}$ & Total & $\begin{array}{c}\text { Urban } \\
(\%)\end{array}$ & Total & $\overline{\text { Urban (\%) }}$ \\
\hline $\begin{array}{l}\text { Population by } \\
\text { domicile (number) }\end{array}$ & 23.118 .745 & 54,31 & 22.170 .568 & 56,40 & -948.177 & $-0,65$ \\
\hline $\begin{array}{l}\text { Resident } \\
\text { population }\end{array}$ & 22.810 .035 & 54,32 & 19.414 .458 & 53,85 & -3.395 .577 & $-0,47$ \\
\hline $\begin{array}{l}\text { Households } \\
\text { (number) }\end{array}$ & 7.470 .429 & 56,32 & 7.494.300 & 53,10 & +23.871 & $-3,22$ \\
\hline Dwellings (number) & 7.682 .359 & 55,89 & 9.031 .300 & 54,57 & +1.024 .951 & $-1,32$ \\
\hline Person/household & 3,05 & 2,94 & 2,59 & 2,62 & $-0,46$ & $-0,32$ \\
\hline Person/dwelling & 2,96 & $2,89 *$ & 2,15 & $2,12 *$ & $-0,80$ & $-0,77$ \\
\hline Household/dwelling & 1,07 & $1,02 * *$ & 1,20 & $1,23 * *$ & $+0,13$ & $+0,21$ \\
\hline
\end{tabular}

*number persons/dwelling; **number households/dwelling

(Sources : authors data processing INS, Tempo ONLINE and

EUROSTAT database, 2018; 1992 Census of population and housing)

Comparing the numerical evolution of the population and that of the number of households with the evolution of the number of dwellings in Romania, certain particularities regarding population/housing ratio, respectively number of households/ number of dwellings can be emphasized. At the end of 2018, Romania had a resident population of 19.41 million inhabitants [7], of which 53.9\% lived in the urban area. According to official statistics, during the period 1992-2018 due to the decrease of the population number (on average, with 150,000 inhabitants /year) and of the increase of the number of households (on average 742/year) there was a slight increase of the number of houses (in average with 37 dwellings per year). We note that, both at the beginning and at the end of the period, the number of existing homes in Romania was higher compared to the number of households and that, while the number of population decreased, the housing stock increased. During this period, the size of the households in Romania decreased from 3,05 persons/household at the end of 1992 to 2,6 in 2018 [8], which is higher than the EU average which reached 2,3 people/household in 2018) [9]. This reality is a consequence of the increase, in the analyzed time interval, of the number of households made up of a single person (from 1.245.227 in 1992 to 2.163.400 in 2018) [10]. Against the background of reducing the size of the household in this interval there was also a decrease in the number of persons/dweeling from 2.96 persons /housing in 1993 to 2.12 in 2018.

A surplus of available housing could be considered a favorable factor, which would facilitate mobility in a stable market environment, but this is not the case of Romania, 
where most of the houses are unoccupied, represent holiday homes (residences), are located in places where housing markets do not work, are substandard (in most cases) or unfinished housing [11]. The dynamics of the housing stock during the period studied, expressed by the annual increase of the number of dwellings per living environment (urban, rural), is shown in Figure 2.

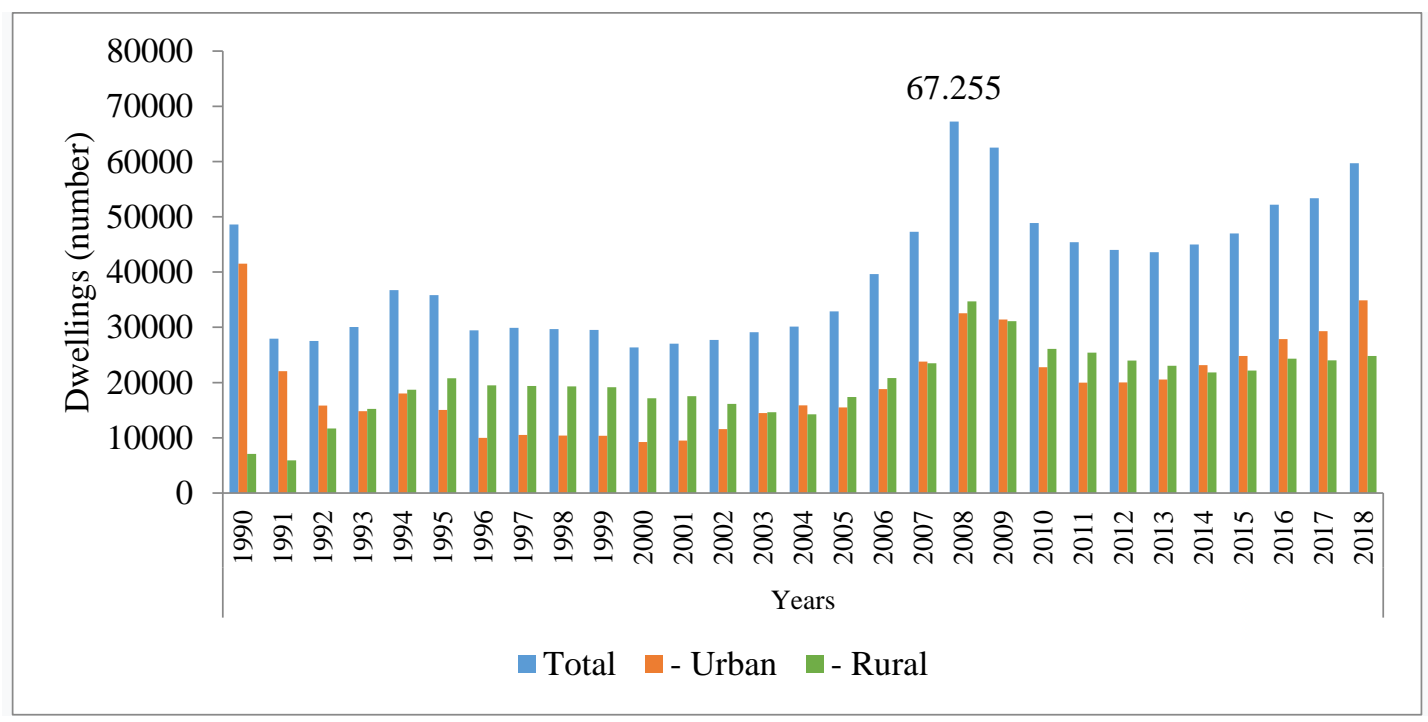

Figure 7. Dynamics of housing construction on living environments in Romania, 1990-2018

(Data processed by the authors from the Tempo ONLINE database of National Institute of Statistics)

The analysis of the graph shows, for the period 1990-2002, a downward trend of housing constructions, followed by a revival starting with 2004, the year 2008 registering itself as the main peak for the entire analyzed period, marked by the maximum value of the number of dwellings completed in one year (67.255). In the second part of the period between 2008-2018, the number of homes built annually decreases (more pronounced in 2010 , consequence of the financial crisis) so that after 2014 it will register a new upward trend until 2018, supported by a more alert rate materialized through higher values compared to the first range. The economic growth registered by Romania in 2017 explains the dynamics in the field of housing construction in recent years. It is estimated that Romania's real GDP increased by $6.7 \%$ in 2017 , after, in 2016, the recorded rate was only $4.8 \%$ [12]. During the communist period, in the context of a policy of industrialization of the country (which mainly targeted small and medium-sized cities) and the pro-birth policy, of a large demand for housing (generated by the reach of generations during the demographic boom of 1967-1980, at the age for the formation of family couples [13] but also for the migration of the population to the cities in full industrialization), the Romanian state promoted a policy of housing development directed especially to the urban environment. Until 1990, most homes were state-owned and Romanian law included numerous restrictions on ownership: the maximum number of dwellings allowed was two (one main and one vacation), the right to settle in large cities it was restricted and there were clear regulations regarding the extension of the built-up area of localities and towns [14]. After 1990, the socio-economic context changed fundamentally, Romania underwent a severe economic restructuring that put its mark on the incomes of the population and materialized at a slow rate of renewal of the housing fund. Although in the years following the Revolution of December 1989, the housing crisis felt strongly, especially in the urban environment. The lack of clear regulations in the field of housing 
construction and the poor financial power of the population were among the most important factors that determined the lack of attractiveness of the housing construction for investors. In the rural area, during the analyzed period, the dynamics of housing construction was, with small exceptions, more pronounced than in the urban environment. Amid the restructuring of the industry, in the years following the December Revolution, numerous factories were closed, in some cases, employees were laid off in the mass. The loss of jobs, the diminution of incomes at the limit of subsistence, the impossibility of sustaining the expenses of the housing, correlated with the retrocession of properties (Law 18/1991) have fed important urban-rural migratory flows. After a long period in which access to property has been limited in Romania by different means, this dynamic can be appreciated as an expression of the population's desire to own a home as a personal property. As a result, the majority of those who emigrated from Romania after 1993 set out to earn more money in order to be able to build their own home in the country. The realization of this desire has led to an increase in the number of homes built especially in the main departure areas of the country, an aspect confirmed by the statistical data. In parallel, the total number of dwellings in the urban area decreased slightly, consequence on the one hand of the exit of the use of many individual dwellings within the cities and on the other hand of the manifestation of the population's preference to build in the surrounding area of the cities, away from their noise and agitation. The economic growth registered in Romania after 2014, the diversification of the labor market and the increase of the number of jobs in the urban areas produced the increase of the income of the population in the cities which caused the change of its preferences for housing. The configuration of a large demand for new, modern, more spacious, brighter homes, equipped to the current standards, was able to strongly boost private investments in this field. Now, the housing becomes more than a shelter, a heritage good, an investment, and by own characteristics and location a trademark of social prestige, a symbol of success [15].

As regards the form of ownership over the home, Romania is distinguished at the level of the U.E. by the highest share of private property. In 1990, the mass privatization of housing began in Romania, which has reduced public ownership housing from 2.615.300 in 1990 to 111.960 in 2018 and increased the share of private sector housing stock from $67 \%$ in 1990 to $99 \%$ in 2018. This fact can be explained, first of all, from a cultural perspective, the desire to have the right of ownership over the land and the home has been, since ancient times, a reason for existence for Romanians. Another argument that justifies the high share of private property is that the Romanian rental market is not yet well organized and regulated enough. The renting of houses, in many cases, is done unofficially, the prices being quite high, especially in the big cities. To these expenses are added those of maintenance of the house, the payment of utilities, which leads, finally, to costs that cannot be covered by the families with medium and small earnings, consequently, the possibility of buying a home seems more advantageous compared to renting. Housing transfer is considered a fair way to promote property rights, but it has led to a decrease in the stock of social houses, and also to a number of difficulties for the new owners to ensure the management and maintenance of the newly acquired houses [16]. The extension of private property over the entire housing stock in Romania has negative consequences on its quality, since the state and local administration can no longer be involved in the maintenance of the buildings in which the houses are located. According to the Government Decision no. 2139/2004, the depreciation period of residential buildings is established between $40-60$ years. This interval can be interpreted 
as the time period in which the building is functional and valid. After the depreciation period, the building could be dangerous for those who use it [17].

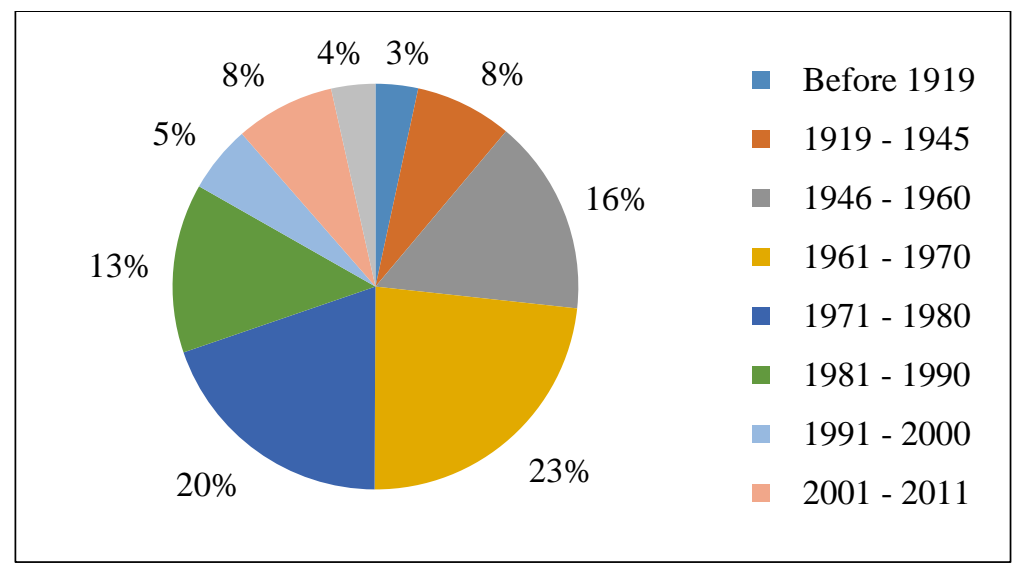

Figure 8. Structure of housing stock in Romania, after the construction period

(Data processed by the authors from the Tempo ONLINE database of National Institute of Statistics)

The statistical data indicate that $70 \%$ of the existing housing fund in Romania has the life span exceeded (or are close to exceeding this limit), in this situation being the majority of the collective housing in the urban area. Most of the dwellings exceeding 4060 years being built in the socialist period (33\%), only $17 \%$ is more recently built, having a less than 30 years old (Figure 3). This situation indicates that a large part of the population of the country lives in dwellings that have exceeded their useful life and requires investments to ensure adequate living conditions.

Another aspect that characterizes the housing stock, significantly from the perspective of housing quality, is the size of the dwelling. The changes produced at the housing fund level are highlighted by the centralized indicators in Table 2 .

Table 2. Romania - indicators of housing stock and housing for 1992 and 2018

\begin{tabular}{lcccccc}
\hline \multicolumn{1}{c}{ Indicators } & \multicolumn{2}{c}{$\mathbf{1 9 9 0}$} & \multicolumn{2}{c}{$\mathbf{2 0 1 8}$} & \multicolumn{2}{c}{ Dinamics } \\
\cline { 2 - 7 } & Total & $\begin{array}{c}\text { Urban } \\
(\%)\end{array}$ & Total & $\begin{array}{c}\text { Urban } \\
(\%)\end{array}$ & Total & Urban (\%) \\
$\begin{array}{l}\text { Habitable } \\
\text { surface area } \\
\text { (square meters }\end{array}$ & 246.847 .073 & 55,53 & 430.008 .586 & 54,97 & +183.161 .513 & $+0,56$ \\
$\begin{array}{l}\text { developed area) } \\
\text { Dwellings } \\
\text { (number) }\end{array}$ & 8.006 .349 & 53,63 & 9.031 .300 & 54,57 & +1.024 .951 & $+0,94$ \\
$\begin{array}{l}\text { Habitable } \\
\text { Surface area/ }\end{array}$ & 30,83 & $31,92^{*}$ & 47,61 & $47,97 *$ & $+16,78$ & $16,05^{*}$ \\
$\begin{array}{l}\text { dwelling } \\
\text { Habitable surface } \\
\text { area /person }\end{array}$ & 10,82 & $11,12^{* *}$ & 22,14 & $22,61 * *$ & $+11,32$ & $+11,49$ \\
$\begin{array}{l}\text { Total number of } \\
\text { rooms }\end{array}$ & 17.997 .751 & 54,02 & 24664313 & 50,64 & +6.666 .562 & $-3,38$ \\
$\begin{array}{l}\text { Average number } \\
\text { of } \\
\text { rooms/dwelling }\end{array}$ & 2,24 & $2,26 * * *$ & 2,73 & $2,53 * * *$ & $+0,51$ & $+0,27$ \\
\hline
\end{tabular}

*square meters developed area/dwelling; ** square meters developed area/person; *** number of rooms/number of dwellings;

(Data processed by the authors from the Tempo ONLINE database of National Institute of Statistics) 
Regarding the size of the dwellings, the statistical data corresponding to the years 1990 and 2018 indicate, overall, an increase for all the selected indicators, except for the indicators regarding the total number of rooms in a dwelling in the urban area and their share in the total of the built dwellings. This is a consequence of rising land prices in the urban environment and, implicitly, the increase in housing prices. As a dwelling has a larger number of rooms, the costs of purchasing and maintaining it increase, so the population prefers the dwellings with 2-3 rooms and the developers in the field of housing construction having to adapt their offer, equally to the market requirements but also to the return on investment. During the analyzed period, a significant increase of the habitable surface area that returns to the average of a person is highlighted: from 10.82sq /person in 1992 to $22.14 \mathrm{sq} /$ person in 2018 . This evolution can be correlated both with the preferences of the population for more spacious housing and with the new regulations in the field of housing construction that impose larger living and usable areas (Law no, 114/1996 amended by Law 143/2017).

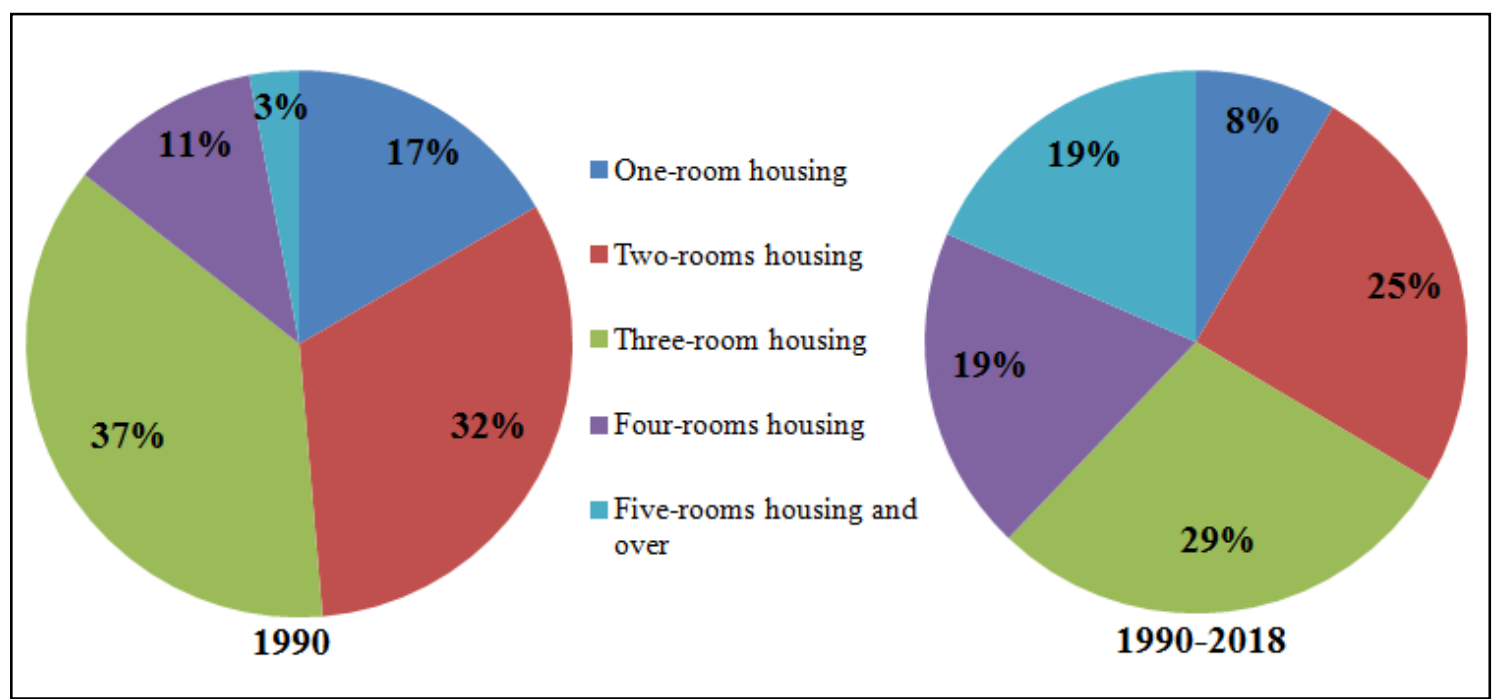

Figure 9. Dwellings whose construction was completed during 1990 and in the period 1990-2018, according to the number of rooms in the house

(Data processed by the authors from the Tempo ONLINE database of National Institute of Statistics)

Thus, if at the beginning of the analyzed period (1990), the share of single-room dwellings owned $17 \%$ of the total housing built in that year, and of those with five rooms it rose only to $3 \%$, the subsequent dynamics highlights an inverse situation, respectively the reduction strong share of single-room dwellings in total, in favor of multi-room dwellings (four, five and over). Two- and three-room dwellings, although they have reduced their share in time (from $69 \%$ to $54 \%$ ), remain well represented in the total number of dwellings raised during this period.

A very important aspect for a qualitative housing is the access of the houses to utilities (electricity, water, sewerage, heating sources). In Romania, during the last three decades, significant progress has been made in terms of access to housing for utilities, but there are significant disparities between cities and villages from this point of view. In general, city dwellings, especially block dwellings are well served in all categories of utilities, while living in villages is experiencing problems with the connection of housing to drinking water distribution and sewerage systems.

The changes that occurred in the analyzed time interval are highlighted in the graph in Figure 5. 


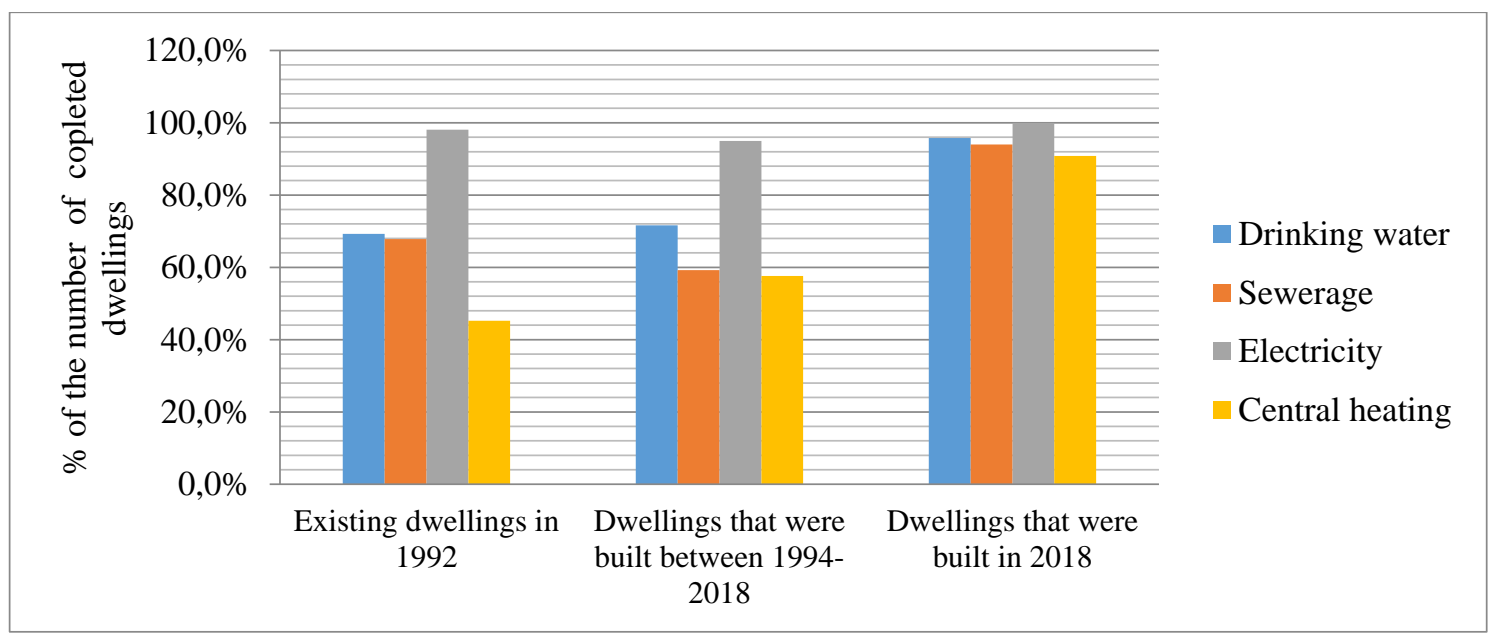

Figure 10. Dwellings built in 1992, between 1994-2018 and 2018, depending on their access to utilities

(Data processed by the authors from the Tempo ONLINE database of National Institute of Statistics)

In $1992,98.1 \%$ of the existing housing stock benefited from electricity, less than $70 \%$ of the homes were connected to drinking water distribution and sewerage systems and only $45.2 \%$ of the homes had central heating. Analyzing the situation of houses whose construction was completed in the period 1994-2018, we find an improvement in the situation regarding the supply of houses with electricity and drinking water and a regression regarding the access to the sewerage and central heating. While the share of households connected to electricity remains high (94.9\%), the share of homes that have access to drinking water distribution systems increases to $71 \%$ of the total, the percentage of dwellings benefiting from sewerage decreases to $59.2 \%$ and of those who benefit from central heating to 57.6\%. Although the trend for the year 2018, illustrated in Figure 5, is to ensure, for all the built housing, the best access to utilities, we must also bear in mind that the national housing fund includes housing built in different periods that do not benefit from these facilities. Another important aspect concerns the cost of these utilities and the readiness of the population to pay more for them. Most of the village population prefers their own water collection and sewerage systems because the costs are lower compared to the ones practiced by the profile companies. In the case of cities, the provision of drinking water and sewage in its own system solves, in most cases, the inability of the local administration to respond to the challenge of rapidly expanding to the outskirts of the inhabited areas.

Another reality, highlighted by the statistical data, is that there are major discrepancies between urban and rural areas in terms of access to housing for utilities. Most of the population living in villages makes their living by practicing agriculture, meaning - the necessary food, because the work in agriculture is poor or not remunerated at all. As a result, villagers have low incomes that do not allow them to spend very much on utilities. Comparing the situation existing at national level regarding the endowment with utilities of the houses built between the 1994-2018, to the one that characterizes the residence environments, we find that the houses in the rural area benefit to a lesser extent from access to utilities compared to those from the urban environment.

Thus, as the graph in Figure 6 also indicates, only $94.3 \%$ of the rural dwellings are connected to the electricity distribution system compared to $95.7 \%$ of the urban dwellings. 


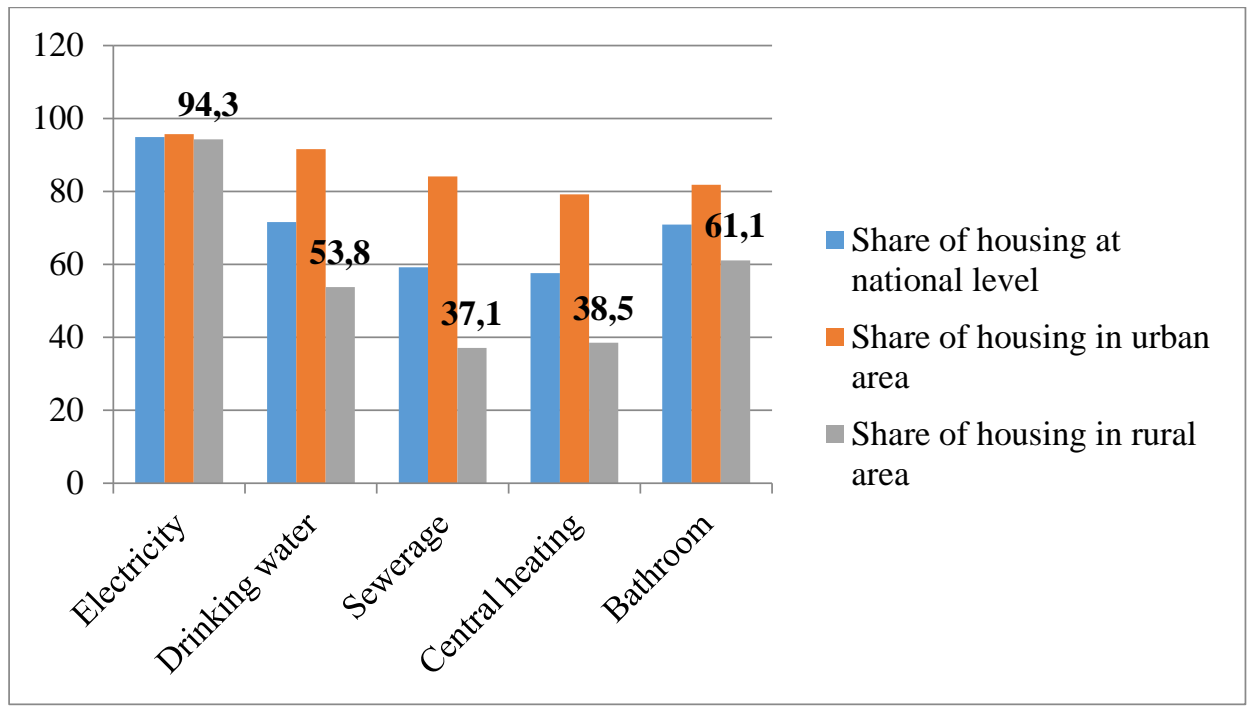

Figure 11. Access to utilities of housing built in Romania during 1994-2018, by living environment

(Data processed by the authors from the Tempo ONLINE database of National Institute of Statistics)

Only $53.8 \%$ of households in rural areas are supplied with drinking water, compared to $91.6 \%$ of dwellings in cities. The most problematic situation is that of the connection to the sewerage, which benefits only $37.1 \%$ of the houses in the villages compared to $84.1 \%$ for the housing in the cities. The lack of sewerage systems has a negative impact on the existence of bathrooms in homes (only $61.1 \%$ of homes have bathrooms inside) but also on their current use. The access of housing to a centralized heating system is limited in the rural area, the majority of the population prefers to heat their homes with stoves, as opposed to the higher share of housing in the urban area that benefit from this service (79.2\%). The existing situation illustrates, on the one hand, the reduced capacity of the local administrations to solve the problems of the community and, on the other hand, the existing imbalance between the cost of the services offered and the financial power of the inhabitants of the villages. In other news, we must also emphasize that this situation puts people in the situation of choosing a situation with which they were already accustomed, which did not involve additional expenses with a situation in which they have to pay for something they already have in another form. In most cases, progress remains, in this situation, an option for the future for many of the inhabitants of the villages.

Although the situation of endowment with utilities has improved in the last decades in Romania, in order to increase the quality of housing there is still a long way to go and large measures and investments are required to bring the Romanian housing fund to at least a level close to the European one.

\section{The dynamics of the regional housing fund, between 1990 and 2018}

In order to highlight the main changes that occurred in the evolution of the housing fund at the regional level, the centralized statistical data of the National Institute of Statistics for the eight development regions of Romania were used, according to the Nomenclature of Territorial Units for Statistics (NUTS I).

For the years 1990 and 2018, data regarding the number of dwellings, the living area, the number of rooms and the endowment of dwellings with utilities were extracted and processed, based on them were derived indicators that illustrate the dynamics of the housing stock and the disparities occurring at the evolutionary level and territorial (by 
comparing the weights corresponding to the regions in the national total and by analysis by means of residence).

The development regions in Romania are differentiated by size, degree of urbanization, number of cities, level of economic development, demographic and cultural models, degree of infrastructure development etc.

The report of the values of the indicators reflecting the evolution of the housing stock by regions (number of dwellings, habitable surface and number of rooms), at the values registered at national level for the period 1992-2018, indicates a quite different situation. This situation is the result of a complex of factors, a significant contribution to shaping the demand and supply of housing having the size, the economic power of the development regions and the presence of large cities with the role of growth poles or centers of polarization.

Table 3. Dynamics of the number of dwellings, of the habitable surface and of the number of rooms within the development regions of Romania, between 1992 and 2018

\begin{tabular}{|c|c|c|c|c|c|c|c|c|}
\hline Region & $\begin{array}{c}\text { Housing } \\
\text { dynamics } \\
\text { between } \\
\text { (number } \\
\text { of } \\
\text { dwellings } \\
\text { /year) }\end{array}$ & $\begin{array}{c}\text { Annual } \\
\text { housing } \\
\text { growth } \\
\text { rate } \\
(\% / \\
\text { year })\end{array}$ & $\begin{array}{c}\text { Annual } \\
\text { dwellings } \\
\text { growth } \\
\text { rate in } \\
\text { urban } \\
\text { areas } \\
(\% / \\
\text { year) }\end{array}$ & $\begin{array}{c}\text { The } \\
\text { dynamics } \\
\text { of } \\
\text { habitable } \\
\text { surface } \\
\text { (sqm. } \\
\text { develope } \\
\text { d area/ } \\
\text { year) }\end{array}$ & $\begin{array}{c}\text { Annual } \\
\text { habitable } \\
\text { surface } \\
\text { growth } \\
\text { rate } \\
(\% / \\
\text { year) }\end{array}$ & $\begin{array}{c}\text { Urban } \\
\text { dynamic } \\
\text { s } \\
\text { of } \\
\text { habitable } \\
\text { surface } \\
\text { (sqm. } \\
\text { develope } \\
\text { d area/ } \\
\text { year) }\end{array}$ & $\begin{array}{c}\text { Annua } \\
\text { l } \\
\text { rooms } \\
\text { growth } \\
\text { rate } \\
(\% / \\
\text { year) }\end{array}$ & $\begin{array}{c}\text { Annu } \\
\text { al } \\
\text { rooms } \\
\text { growt } \\
\text { h rate } \\
\text { in } \\
\text { urban } \\
\text { areas } \\
\text { (\%) } \\
\text { year) }\end{array}$ \\
\hline $\begin{array}{l}\text { North- } \\
\text { West }\end{array}$ & 5681 & 0,56 & 0,66 & 897626 & 2,78 & 493623 & 1,71 & 1,31 \\
\hline Center & 3511 & 0,37 & 0,48 & 761626 & 2,54 & 474048 & 1,43 & 1,16 \\
\hline $\begin{array}{c}\text { North- } \\
\text { East }\end{array}$ & 8375 & 0,68 & 0,75 & 1083945 & 3,01 & 431575 & 1,68 & 1,19 \\
\hline $\begin{array}{c}\text { South- } \\
\text { East }\end{array}$ & 5213 & 0,53 & 0,53 & 800436 & 2,57 & 394460 & 1,16 & 0,82 \\
\hline $\begin{array}{l}\text { South- } \\
\text { Muntenia }\end{array}$ & 5476 & 0,45 & 0,50 & 944703 & 2,63 & 376162 & 1,21 & 0,92 \\
\hline $\begin{array}{c}\text { Buchares } \\
\text { t-Ilfov }\end{array}$ & 3784 & 0,40 & 0,38 & 828558 & 2,76 & 690705 & 0,88 & 0,77 \\
\hline $\begin{array}{c}\text { South- } \\
\text { West }\end{array}$ & 2918 & 0,33 & 0,71 & 639074 & 2,55 & 321936 & 1,30 & 1,30 \\
\hline West & 1647 & 0,21 & 0,35 & 585516 & 2,22 & 364681 & 1,19 & 0,95 \\
\hline $\begin{array}{c}\text { National } \\
\text { total }\end{array}$ & 3660 & 0,46 & $\mathbf{0 , 5 3}$ & 6541483 & 2,65 & 3547194 & 1,32 & 1,02 \\
\hline
\end{tabular}

(Data processed by the authors from the Tempo ONLINE database of National Institute of Statistics)

With an increased dynamics of the pace of increase in the number of dwellings, the NorthEast and North-West Region are noticeable, this evolution being correlated with the high demand for housing in these regions. In the North-East Region, at the end of 2018, according to statistical data, $16,5 \%$ of the total resident population in Romania lived, which represents the highest share of all the regions $(3,968,040$ inhabitants by domicile and 3,198,564 resident inhabitants in 2018 [19]). A significant role in the increase of the number of dwellings also had the cultural model, as we have emphasized, the valuation of the property being a specific feature to the Romanian people. For most households, housing is the main reason for living, and the property is equivalent to family stability and continuity, becoming an exponent of the standard of living, an opportunity to prove 
belonging to a community and, at the same time, successful in life. After 1990, the houses were built mainly from private funds, respectively from population funds. The funds that ensured the possibility of building new homes came from the sale by the owners of the apartments bought in the communist blocks and the money that the emigrants sent for the construction of their own homes on the territory of the country $(1 / 3$ of the number of emigrants from Romania come from the North-East Region), but also as a result of the increase of incomes and the improvement of the standard of living determined by the economic growth achieved by Romania (and implicitly by these regions) during this time period.

At the opposite pole, with the lowest housing stock and the slowest growth rate, the West region is a less populated region, characterized by the lowest values of population density, which was strongly affected by deindustrialization after 1990 .

The process of deindustrialization after the Revolution of December 1990 led to the dismissal of a large number of people and, implicitly, to the decrease of the incomes and the purchasing power of the population, an aspect that was negatively reflected on the demand for housing. Regarding the annual rate of growth of the number of dwellings, only three regions (North-East, North-West, South-East) had a rate of growth higher than the national one, with the highest value $(0.68 \%$ /year) also registering the North-East Region, with the lowest value of the growth rate $(0.21 \%$ /year) returning to the West Region. The annual rate of growth of the number of dwellings in the urban environment, outpaces the growth rate from the rural area in the vast majority of the regions, with the exception of the South-East Region in which the rates register with equal values and the Bucharest-Ilfov Region in which the annual rate of growth is higher in rural areas. This situation is the result of the functional diversification and territorial expansion of the capital to the adjacent spaces as a result of the urban expansion phenomenon [20], also of the lack of land for construction inside the capital but also of their very high prices, which orient the buyers and investors to the most accessible land for price in the rural areas of Ilfov county. During this period, the capital's industry went through a process of restructuring, deindustrialization and relocation of some companies in Ilfov [21], which also caused the change of the population's residence near the work places in order to avoid the agglomeration produced in traffic at peak hours on the streets of the capital city. A particular situation is recorded in the West Region where the annual growth rate of the number of dwellings in the rural area has negative values, due to the fact that this region has the lowest number of inhabitants, within the region the rate of economic growth is differentiated, with values large in the city of Timisoara and small values in the communes.

The annual growth rate of the total number of dwellings at the level of the component counties of the development regions and by residence area is shown in the map in Figure 7.

Reporting the values of the annual growth rates of the total number of dwellings registered at the county level at the national average $(0.46 \%)$, we emphasize that 6 counties have a pronounced dynamic, demonstrated by the high values of the growth rate (over $0.76 \%$ and over 1\%), 15 counties have registered improvements in housing, the rate exceeding the national average, with increases between $0.51-0.76 \%$, while 12 counties had a slower dynamic marked by modest increases (below $0.25 \%$ ). 


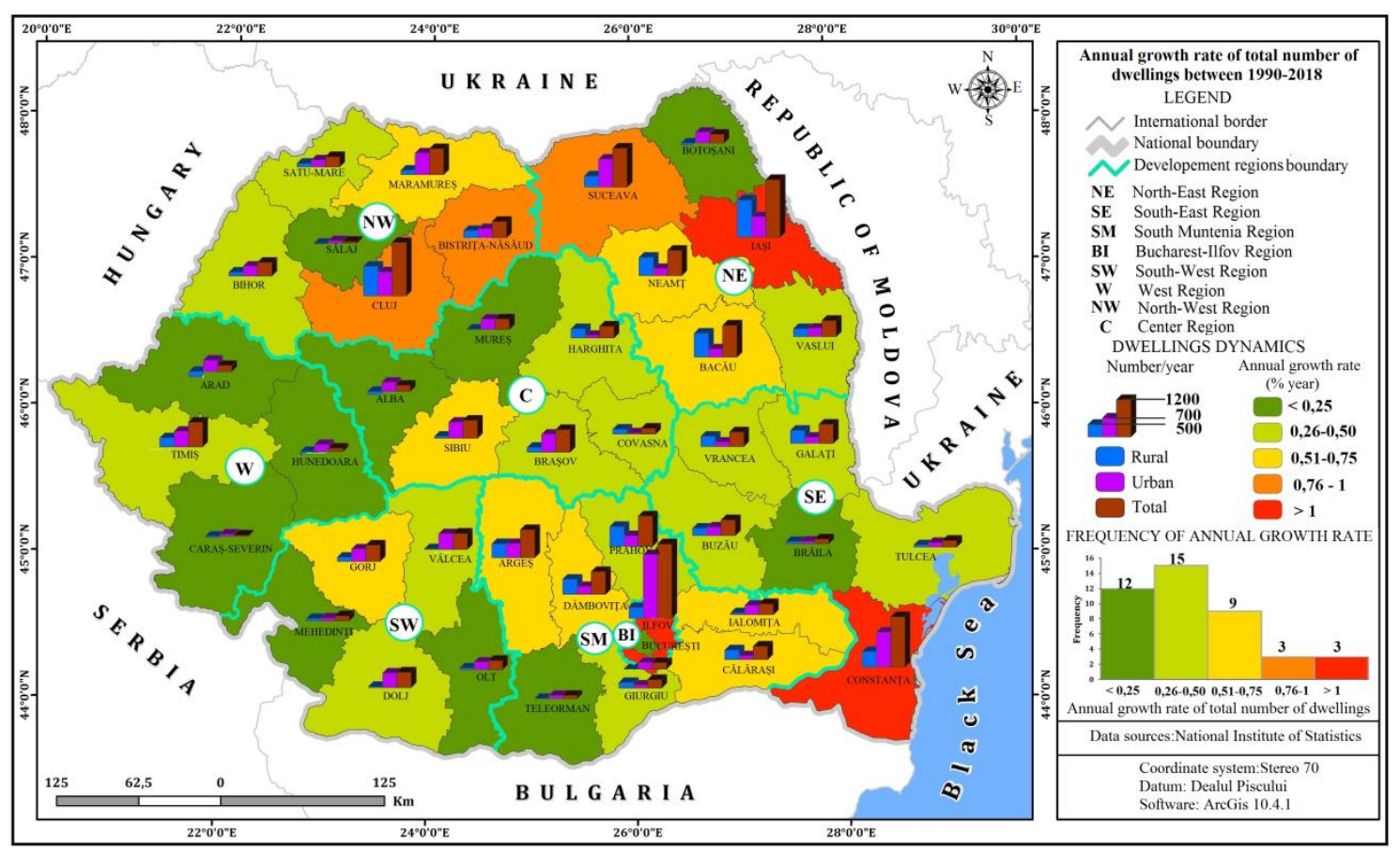

Figure 12. Annual growth rate of the total number of dwellings în Romania, between 1990 and 2018, at the level of the development regions and their component counties (Data processed by the authors from the Tempo ONLINE database of National Institute of Statistics)

The analysis of the values of the annual growth rate of the total number of dwellings at the scale of the component counties of the development regions highlights interesting aspects. Thus, in most cases, we observe the existence, within the development regions, of counties that had a more pronounced dynamics translated into higher values compared to the other counties: for example Iași and Suceava for the North-East Region; Constanța for the South-East region; Ilfov for the South-Muntenia Region; Gorj for the South-West Region; Timiş for the West Region, Sibiu for the Centru Region, Cluj and Bistriţa-Năsăud for the North-West Region. In other situations, the territorial dynamics are very different, the component counties having very different values of the growth rate, from the lowest to the highest (North-East Region; North-West Region, South-Muntenia Region) or, on the contrary, quite homogeneous (West Region).

The dynamics on the two residence environments (urban and rural) highlights the fact that, at national level, in 28 counties of the country, the value of the number of houses built annually was higher in the rural area than in the urban area, only in 12 counties the number of dwellings built in the urban area was higher than in the rural area, in two counties the number of dwellings built in the urban area being close to the value of the one in the rural area. At the level of the development regions, the situation is as follows: in the North-East region and in the North-West Region, the number of counties in which several dwellings were built in the urban environment predominates; in the South-West, West, Bucharest-Ilfov regions, in all counties the number of dwellings built in rural areas exceeded that of urban areas; in the South-East, North-West and Center regions, there are a greater number of counties in which houses were built in rural areas.

Analyzing the situation of the dynamics of the habitable surface (Table 3), with an accentuated dynamic of the living area, it is noted, the North-East Region (16.5\% of the value realized at national level), followed by the South - Muntenia Region (14.4\%) and the North-West Region (13.7\%). The smallest increases were in the West and South West 
Region. The same situation is noted for the value of the annual rate of growth of the housing surface, the South-Muntenia region being outpaced at this indicator by the Bucharest-Ilfov region. The increase of the housing surface in the urban area reached the highest value in the Bucharest-Ilfov Region (19.5\% of the national value), the NorthWest, Central and North-East regions, also noticing higher values with the other regions.

On a smaller territorial scale, within the regions, the dynamics of the living area recorded a different rate of growth from one county to another, a fact illustrated by the map in Figure 8.

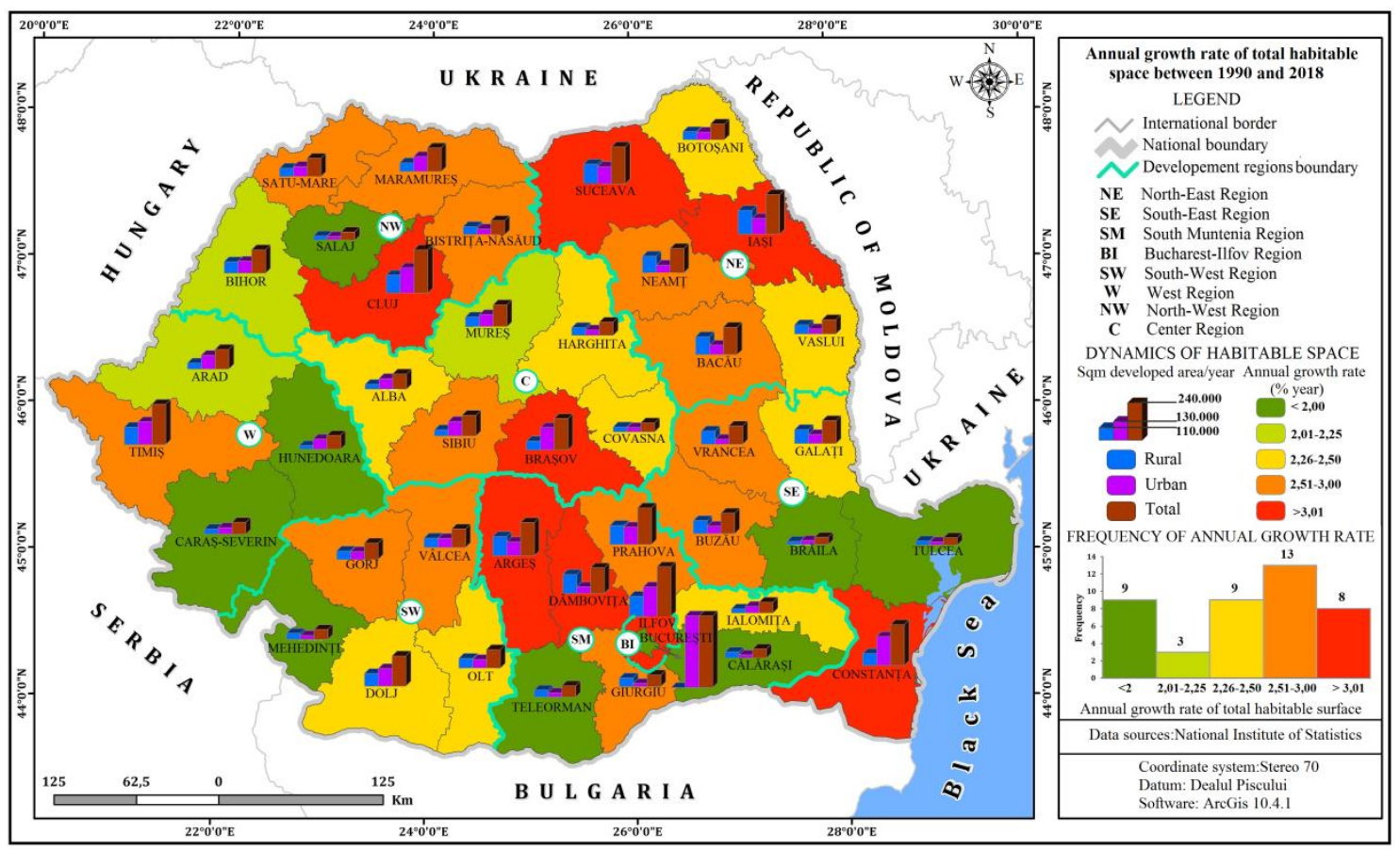

Figure 13. Annual growth rate of the total habitable surface in Romania, between 1990 and 2018, at the level of the development regions and their component counties (Data processed by the authors from the Tempo ONLINE database of National Institute of Statistics)

Reporting the values of the annual growth rates of the total habitable space registered at the county level at the national average $(2,65 \%)$, we emphasize that 21 counties have a pronounced dynamic, demonstrated by the high values of the growth rate (over 2,51\% and $3.01 \%), 9$ counties had an average rate of increase of the living area with values that tend towards the national averagethe rate having values close to or below the national average (2,26-2,50\%), while 9 counties had a slower dynamic marked by modest increases (below 2\%).

Within the regions, at the level of their component counties, with the highest values of the annual rate of increase of the habitable surface, both the counties were noted, which were noted by an accentuated dynamics of the housing constructions but also other counties (Argeș and Dâmbovița from the South-Muntenia Region; Vâlcea from the South-West Region; Brașov from the Center Region; Maramureș and Satu-Mare in the North-West Region). The lowest annual growth rates are counted in Braila, Teleorman, Mehedinți, Caraș-Severin, Sălaj, Tulcea and Călărași counties. We can also see that the rural area has registered more pronounced increases in the living area in most regions, except for the North-East and South Muntenia regions where the growth was more pronounced in the urban area. 
Analyzing the growth rate of the number of rooms at the regional level (Table 3), we observe that in the North-West, Central and North-East regions the growth rate is high, the Bucharest-Ilfov Region registering with the lowest value. At the urban level, the highest rates of increase in the number of rooms were registered in the North-West, SouthWest and North-East regions, the Bucharest-Ilfov region registering a modest increase. The evolution of the structure of the housing stock built during the period 1990-2018 according to the number of rooms at the level of the development regions is presented in Figure 9.

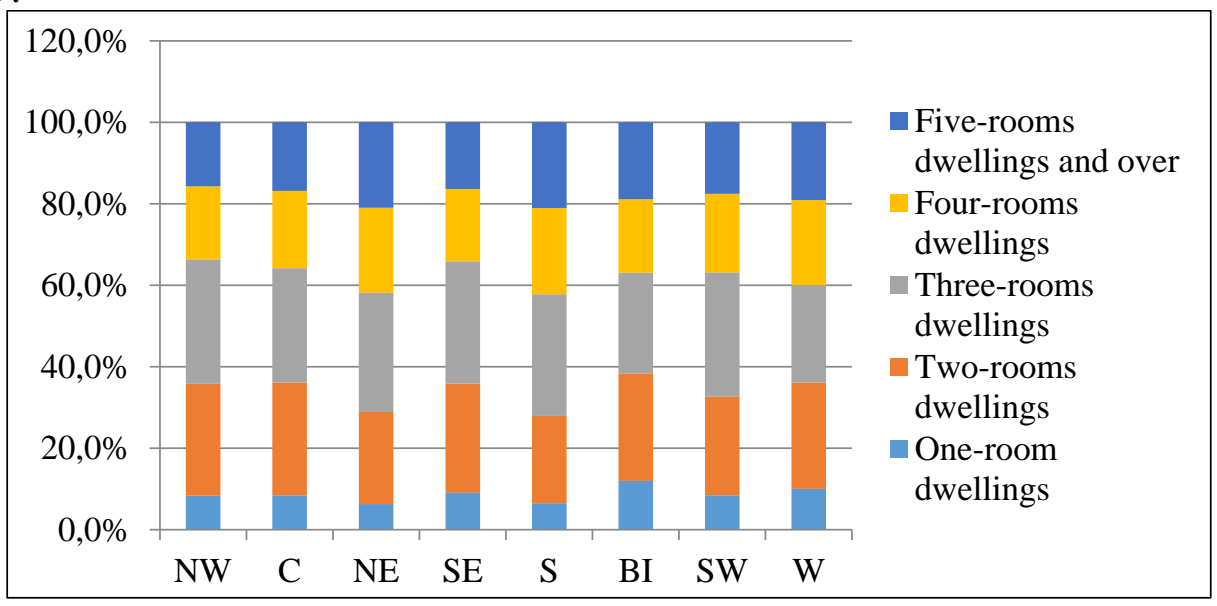

Figure 14. Dynamics of the number of dwellings in the development regions of Romania, between 1990-2018, in relation to the number of rooms of the dwelling

(Data processed by the authors from the Tempo ONLINE database of National Institute of Statistics)

It is noted that, in the majority of regions, a significant share of the total number of dwellings built during the period analyzed is owned by the three-room dwellings (the highest share in the North-West, Center, North-East, South-East, South ) and those with two rooms (they hold the highest shares in the Bucharest-Ilfov Region and the SouthWest Oltenia Region and the second share in all the other regions). Four-room dwellings have the following weight in most regions (with the exception of Bucharest, where fiveroom dwellings have higher weights than four-room dwellings. The last place as a share is five-room dwellings, followed by single rooms. for three-room dwellings it is related to meeting the need for space, even in the case of smaller households, for three persons, and that for two rooms is related to the accessibility as a price for both the purchase and of maintenance expenses.

The annual growth rate of the total rooms number at the level of the component counties of the development regions and by residence area is shown in the map in Figure 10. Reporting the values of the annual growth rates of the total rooms number registered at the county level at the national average $(1,32 \%)$, we emphasize that 26 counties have a pronounced dynamic, demonstrated by the high values of the growth rate (over 1,26\% and over 1,51\%), 9 counties have registered improvements in number of rooms, the rate having values close to or below the national average, with increases between $1-1.25 \%$, while 7 counties had a slower dynamic marked by modest increases (below 1\%). If in the situation of the number of dwellings and the most dynamic living area the rural areas have been proved, in the case of the annual increase of the number of rooms, the urban environment is clearly imposed (30 counties). This situation can be explained by the vertical development of many cities and by the preference for the construction of blocks, while in the rural areas the individual dwellings predominate. 


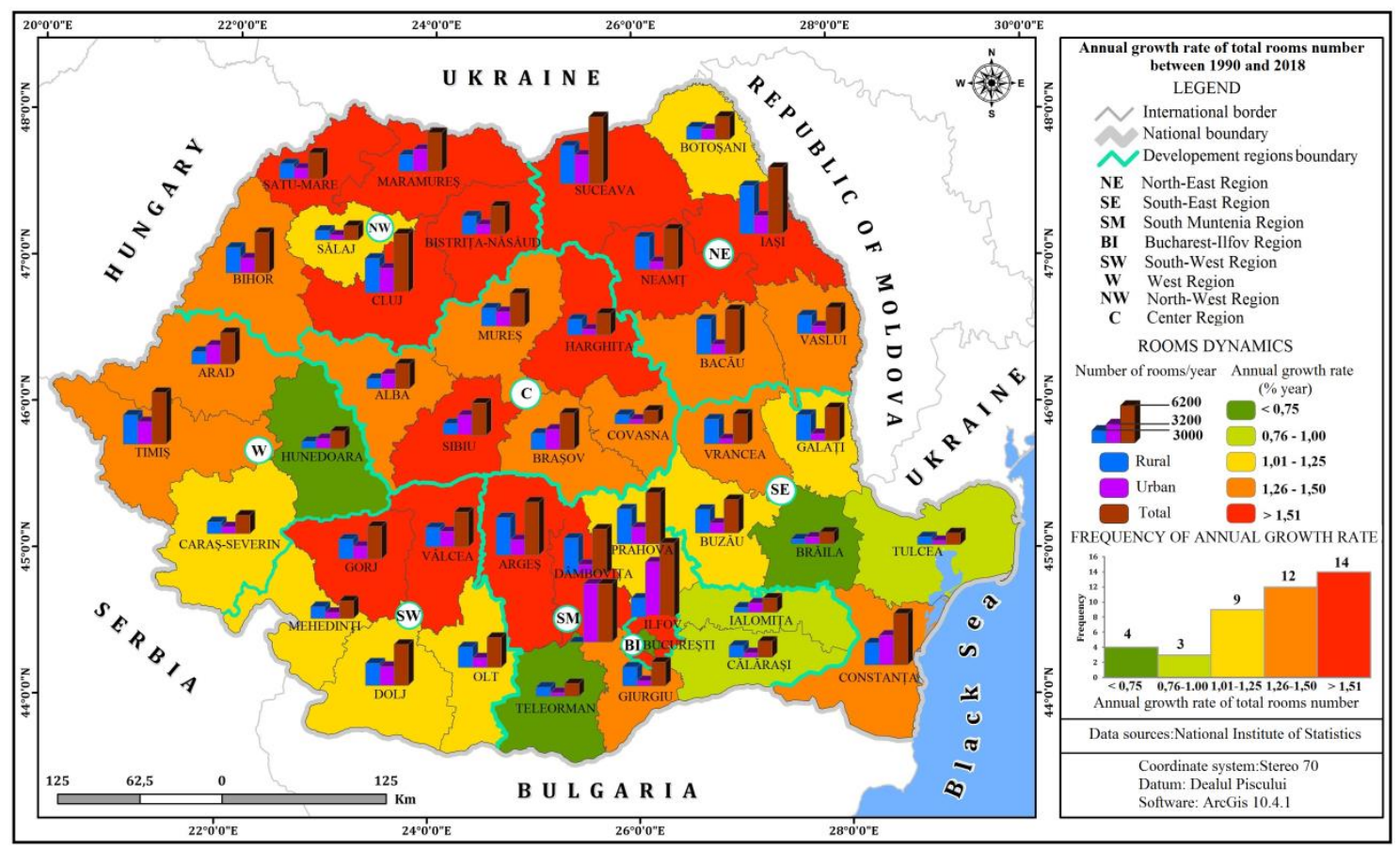

Figure 15. Annual growth rate of the total number of rooms in Romania,

between 1990-2018, at the level of the development regions and their component counties

(Data processed by the authors from the Tempo ONLINE database of National Institute of Statistics)

Overall, the analysis reveals a series of disparities existing in the dynamics of the housing fund at regional level. Thus, the North-East Region is by far the most dynamic of the housing fund, marked by the highest values of growth in the number of dwellings, the dwelling area, the annual growth rate and the number of dwellings in the environment urban. The North-West region also has a similar dynamic, with the highest values at the rate of increase of the number of rooms in total and in the urban environment, and at the other indicators values close to those of the North-East Region. Modest increases in all indicators and the least pronounced dynamics in relation to the other regions are recorded by the Western Region and the South-West Region, however, the latter is noticeable with a good rate of increase in the number of rooms in the urban area. The other regions have an intermediate situation, which approaches more or less the value of the growth rate registered at the national level or they hold significant weights from the national total at different indicators. The Bucharest-Ilfov region, although it has lower values than other regions, we consider that during the analyzed period a dynamic of the housing stock accentuated because the region has the smallest surface between the regions of the country ( $1 / 3$ of the average surface of a region, $0.8 \%$ of the country's surface) and a number of inhabitants close to that of the other regions.

\section{CONCLUSIONS}

The period 1990-2018 was characterized by profound changes on all levels of social economic life, changes that had a major influence on the dynamics of the housing fund. Old age of the housing fund, increase of the number of households (especially of the oneperson population), modification of the housing legislation, modification of the population's housing preferences, lack of clear regulations on the housing rental market, the desire of the population to have a home in personal property are only a few of the factors that contributed to the manifestation of a high demand for housing during the 
whole period. The field of housing constructions has experienced a rather contrasting evolution in this period, as a result of the decrease of public investments after 1990, the manifestation of the economic crisis, the increase of land prices and construction materials, consequently, we appreciate that there has always been an imbalance between the demand and supply of housing

Of the most important aspects that highlight the dynamics of the housing stock during the analyzed period we emphasize: the increase of the total number of dwellings, the increase of the total habitable area and the doubling of the inhabitable area related to a person; significant increase of the habitable area/housing and the number of rooms/housing; maintaining a high share of two- and three-room dwellings and a marked increase in the share of four- and five-room dwellings; an overall improvement of the access of the houses to utilities, especially in the urban environment. The highest annual growth rates for all the analyzed indicators were registered in most counties of the country in the rural area, which is the result on the one hand of the space crisis and of the urban spillover to the neighboring rural areas and, on the other. part of the investments that the emigrants made to raise their own homes in the country.

At the moment, the housing fund in Romania is not burdened by major deficiencies in terms of quantity, we can still emphasize a number of issues that reflect negatively on housing: the housing fund is $99 \%$ privately owned, which limits the possibility of the intervention of the local authorities for repairs and maintenance; most of the dwellings have an outdated lifespan (or are close to this time), being mostly collective dwellings in the urban environment; their rehabilitation or replacement poses major financial, economic and social problems; household equipment is a major problem, especially in rural areas.

\section{Acknowledgement:}

This work is supported by project POCU/380/6/13/125040, entitled "Development of the tertiary university education to support the economic growth - PROGRESSIO", cofinanced by the European Social Fund under the Human Capital Operational Program 2014-2020.

\section{REFERENCES}

[1]***National Institute of Statistics, Housing Fund. Year 2018, Romania, pp. 5, 2019.

[2] Alpopii C., European context and housing trends in Romania, in Public Administration and Management, Romania, no. 8, pp. 74-80, 2007.

[3]***National Institute of Statistics - Housing Fund. Year 2018,, pp.69.

[4]***The housing stock - Analysis sheet of the Observatory of Territories, 2017, publication of the Commissariat-General of the Equality of Territories (CGET), available at http://www.observatoire-des- territories.gouv.fr, pp.1.

[5] Vîrdol, D., Suditu, B., Dumitrache, L., Vâlceanu, DG, Dynamics of housing stock in Romania - between politics and policies, Journal of Studies and Research in Human Geography, Romania, Vol. 9, No 2, pp. 207-223, 2015.

[6] Vîrdol, D., Suditu, B., Dumitrache,L., Vâlceanu, D.G., Dynamics of housing stock in Romania - between politics and policies, Journal of Studies and Research in Human Geography, Romania, Vol. 9, No. 2, pp.207-223, 2015.

[7]***National Institute of Statistics - Housing Fund. Year 2018, Romania, pp. 5, 2019. 
[8] Eurostat - Number of private households by household composition, number of children and age of youngest child, 2018, available at (lfst_hhnhtych).

[9]***National Institute of Statistics - Tempo Base ONLINE - Population residing on January 1st by age groups and sexes and areas of residence, macroregions, development regions and counties.

[10] Alpopi, C., Iacoboaea, C., Stănescu, A., Analysis of the current housing situation in Romania in the European context, Transylvanian Review of Administrative Sciences, Romania No. 43 E, pp. 5-24, 2014.

[11]***National Institute of Statistics, Living Conditions of the Population of Romania, in 2018, Romania, pp. 1-116, 2019.

[12] European Commission (2018a) 2018 Country Report for Romania, SWD (2018) 221 final, Belgium, pp. 1-76, 2018.

[13] Alpopii C., European context and trends of living in Romania, Administration and public management, Romania, no. 8, pp. 74-80, 2007.

[14] Suditu, B., Urban Sprawl - The Legal Context And Territorial Practices In Romania, Human Geographies - Journal of Studies and Research in Human Geography, Romania, vol. 6, no. 1, pp. 73-77, 2012.

[15] Suditu, B., Urban sprawl and residential mobilities in the Bucharest area - reconfiguration of a new residential geography, Human Geographies - Journal of Studies and Research in Human Geography, Romania, vol. 4, no. 2, pp. 79-93, 2009.

[16] Alpopi, C., Iacoboaea, C., Stănescu, A., Analysis of the current housing situation in Romania in the European context, Transylvanian Review of Administrative Sciences, Romania No. 43 E, pp. 5-24, 2014 .

[17] Alpopi, C., Iacoboaea, C., Stănescu, A., Analysis of the current housing situation in Romania in the European context, Transylvanian Review of Administrative Sciences, Romania No. 43 E, pp. 5-24, 2014 .

[18]***National Institute of Statistics, Romanian Statistical Yearbook, 2018, Romania, 2019.

[19]***National Institute of Statistics, Tempo ONLINE database, Population by domicile and resident population on January 1, 2019.

[20] Bălteanu, D., Dumitrașcu, M., Geacu, S., Mitrică, B., Sima, M., - In book: Romania. Nature and Society, Chapter: The geographical characterization of the development regions, Romania, pp.621-652, 2016.

[21] Bălteanu, D., Dumitrașcu, M., Geacu, S., Mitrică, B., Sima, M., - In book: Romania. Nature and Society, Chapter: The geographical characterization of the development regions, Romania, pp.621-652, 2016. 